Review began 09/22/2021 Review ended 10/05/2021 Published 10/11/2021

\section{(๑) Copyright 2021}

Baroud et al. This is an open access article distributed under the terms of the Creative Commons Attribution License CC-BY 4.0., which permits unrestricted use, distribution, and reproduction in any medium, provided the original author and source are credited.

\title{
New-Onset Type 1 Diabetes Mellitus After Treatment With Nivolumab for Melanoma
}

\author{
Sarah Baroud $^{1}$, Lubna Mirza ${ }^{2}$ \\ 1. Department of Internal Medicine, Sheikh Khalifa Medical City, Abu Dhabi, ARE 2. Department of Endocrinology, \\ Norman Regional Health System, Norman, USA
}

Corresponding author: Sarah Baroud, skbaroud@gmail.com

\begin{abstract}
A 67-year-old female taking Nivolumab for melanoma developed a hyperglycemic emergency requiring hospital admission. She was referred to our endocrinology clinic post-discharge where she was diagnosed with new-onset Type 1 diabetes mellitus. Severe hyperglycemia and immune-mediated diabetes mellitus are extremely rare but potentially life-threatening side effects of Nivolumab.
\end{abstract}

Categories: Endocrinology/Diabetes/Metabolism, Internal Medicine, Oncology

Keywords: melanoma, immunotherapy, nivolumab, hyperglycemia, type 1 diabetes

\section{Introduction}

Type 1 diabetes mellitus (T1DM) is an autoimmune disease that affects nearly 1.4 million adults in the United States [1]. Genetic risk factors include individuals with HLA-risk genotypes DR3/4-DQ8 or DR4/DR4 and a positive family history [2]. Non-genetic risk factors include immunization, diet, socioeconomic status, obesity, vitamin D deficiency, perinatal factors, and a history of viral infections, in particular enterovirus infections. Traditional studies have alluded the cause of T1DM to the immune system inappropriately producing antibodies against its own pancreatic $\beta$-cells, the prime source of insulin production [3]. However, newer studies have shown that a fault in the gene sequence of $\beta$-cells, which is predominantly seen following immunotherapy treatment, may be the underlying cause behind the inappropriate activation of the immune system [4].

The autoimmune destruction of pancreatic $\beta$-cells results in a rise in blood glucose levels due to the depletion of insulin, an essential protein regulator of blood glucose [5]. An individual may remain asymptomatic until an incidental discovery is made during routine screening [3], or they may manifest clinically with polyuria, polydipsia, weight loss, fatigue, dyspnea, vomiting, abdominal pain, polyphagia, somnolence, lethargy, and even coma. Diabetic ketoacidosis is a life-threatening medical emergency that is most often the first presentation of T1DM [6].

Nivolumab is a human immunoglobulin G4 (IgG4) monoclonal antibody used in the treatment of colorectal cancer, head and neck cancer, hepatocellular carcinoma, melanoma, renal cell cancer, lung cancer, urothelial carcinoma, and Hodgkin's lymphoma. It works by blocking programmed death 1 (PD-1) receptor, an immune system checkpoint and cell surface protein found on activated T-cells, from binding to programmed death ligand 1 (PD-L1). This disruption in the PD-1/PD-L1 axis, which is responsible for modulating T-cell activity and critical in tumorigenesis, restimulates the immune system's anti-neoplastic activity, resulting in a decrease in tumor growth and consequently, an increase in autoimmune-associated side effects. Severe hyperglycemia and immune-mediated diabetes mellitus secondary to Nivolumab are rare side effects occurring in less than $\leqslant 1 \%$ of patients with a median time to onset of 12 weeks (range: 5-34 weeks) from the start of treatment $[7,8]$.

In this case report, we discuss the case of a 67-year-old female who presented to the hospital with hyperglycemia-related signs and symptoms six weeks after initiating Nivolumab immunotherapy for melanoma. Predominant findings included polyuria, polydipsia, dehydration, fatigue, and an elevated blood glucose level, and she was admitted for a life-threatening hyperglycemic emergency. The patient was treated and subsequently discharged, and was referred to our endocrinology clinic for further workup where a diagnosis of new-onset T1DM was made.

\section{Case Presentation}

A 67-year-old Caucasian woman was referred to our clinic for newly diagnosed hyperglycemia. For the past year, she had been following up with us for her thyroid disease. She has had Hashimoto's Thyroiditis for the last 15 years and has been controlling it with Levothyroxine and Liothyronine Sodium. Her medical history was also remarkable for a melanoma on her left forearm that was treated surgically 5 years prior. Axillary sentinel lymph nodes had been removed at the time and showed no metastases. No chemotherapy or radiation was required and regular follow-up with her dermatologist has shown no signs of recurrence since. 


\section{Cureus}

Her family history is negative for thyroid cancer, functional thyroid disease, diabetes, or autoimmune diseases. During her last visit, which was 2 months before her admission to the hospital, her labs showed a normal blood glucose level (Table 1).

\begin{tabular}{|c|c|c|}
\hline Lab Marker & Finding & Reference \\
\hline White Blood Count & 5.4 & 4.5-11.0 10*9/L \\
\hline Red Blood Count & 4.80 & $4.00-5.2010 * 12 / \mathrm{L}$ \\
\hline Hemoglobin & $15.2 \mathrm{~g} / \mathrm{dl}$ & $12.0-16.0 \mathrm{~g} / \mathrm{dl}$ \\
\hline Hematocrit & $43.6 \%$ & $36.0-46.0 \%$ \\
\hline Mean Corpuscular Volume & 90.8 & $80.0-100.0 \mathrm{fl}$ \\
\hline Platelet Count & 313 & 150-400 10*9/L \\
\hline Sodium & $137 \mathrm{mmol} / \mathrm{L}$ & 136-144 mmol/L \\
\hline Potassium & $4.7 \mathrm{mmol} / \mathrm{L}$ & 3.4-5.1 mmol/L \\
\hline Calcium & $10.4 \mathrm{mg} / \mathrm{dl}$ & $8.4-10.0$ mg/dl \\
\hline Chloride & $105 \mathrm{mmol} / \mathrm{L}$ & 100-109 mmol/L \\
\hline Carbon Dioxide & $25 \mathrm{mmol} / \mathrm{L}$ & 24-32 mmol/L \\
\hline Anion Gap & 12 mEq/L & 9-14 mEq/L \\
\hline Blood Urea Nitrogen & 19 mg/dl & $7-20$ mg/dl \\
\hline Creatinine & $0.83 \mathrm{mg} / \mathrm{dl}$ & $0.60-1.20 \mathrm{mg} / \mathrm{dl}$ \\
\hline GFR, Estimated & $>60 \mathrm{ml} / \mathrm{min}$ & $>60 \mathrm{ml} / \mathrm{min}$ \\
\hline Glucose & 93 mg/dl & 65-100 mg/dl \\
\hline Bilirubin Total & $0.4 \mathrm{mg} / \mathrm{dl}$ & $0.3-1.4 \mathrm{mg} / \mathrm{dl}$ \\
\hline AST & $17 \mathrm{IU} / \mathrm{L}$ & 15-44 IU/L \\
\hline ALT & $21 \mathrm{IU} / \mathrm{L}$ & 15-44 - IU/L \\
\hline Total Protein & $7.2 \mathrm{~g} / \mathrm{dl}$ & $6.1-7.9 \mathrm{~g} / \mathrm{dl}$ \\
\hline Albumin & $4.5 \mathrm{~g} / \mathrm{dl}$ & $3.5-5.1 \mathrm{~g} / \mathrm{dl}$ \\
\hline ALP & $95 \mathrm{U} / \mathrm{L}$ & 41-126 U/L \\
\hline TSH & $1.79 \mathrm{mlU} / \mathrm{L}$ & $0.49 \mathrm{mlU} / \mathrm{L}-4.00 \mathrm{mlU} / \mathrm{L}$ \\
\hline Free T3 & $3.61 \mathrm{pg} / \mathrm{ml}$ & $2.3 \mathrm{pg} / \mathrm{ml}-4.4 \mathrm{pg} / \mathrm{ml}$ \\
\hline Free T4 & $1.01 \mathrm{ng} / \mathrm{dl}$ & $0.60 \mathrm{ng} / \mathrm{dl}-2.00 \mathrm{ng} / \mathrm{dl}$ \\
\hline
\end{tabular}

\section{TABLE 1: Laboratory investigations at our clinic 2 months before hospital admission}

ALT: alanine transaminase; ALP: alkaline phosphatase; AST: aspartate aminotransferase; GFR: glomerular filtration rate; TSH: Thyroid-stimulating Hormone; T4: Thyroxine; T3: Triiodothyronine; dl: deciliter; fl: femtoliters; g: grams; IU: international unit; L: liter; mEq: milliequivalent; mg: milligram; mIU: milli-international units; ml: milliliter; mmol: millimole; ng: nanograms; pg: picograms; U: Units

A medical examination was only notable for a BMI of $29 \mathrm{~kg} / \mathrm{m} 2$ (normal reference range: 18.5 to $24.9 \mathrm{~kg} / \mathrm{m} 2$ ); she had no clinical signs of thyromegaly, lymphadenopathy, acanthosis nigricans, or vitiligo. We had asked her to follow-up with us in the next 6 months.

During this time, she had consulted her dermatologist for a melanoma on her chin. The melanoma on her chin was removed surgically and she was advised to start immunotherapy with Nivolumab once every two weeks. During her sixth week of treatment, she was admitted to the hospital with fatigue, dry mouth, excessive thirst, and excessive urination. Laboratory findings at the time of presentation are provided below (Table 2) and were consistent with a diagnosis of diabetic ketoacidosis (DKA). 


\section{Cureus}

\begin{tabular}{|c|c|c|}
\hline Lab Marker & Finding & Reference \\
\hline POC Sodium & $137 \mathrm{mmol} / \mathrm{L}$ & 136-144 mmol/L \\
\hline POC Potassium & $6.7 \mathrm{mmol} / \mathrm{L}$ & 3.4-5.1 mmol/L \\
\hline POC Chloride & $111 \mathrm{mmol} / \mathrm{L}$ & 100-109 mmol/L \\
\hline POC Magnesium & $2.9 \mathrm{mmol} / \mathrm{L}$ & $0.85-1.10 \mathrm{mmol} / \mathrm{L}$ \\
\hline POC Ionized Calcium & $1.25 \mathrm{mmol} / \mathrm{L}$ & $1.15-1.30 \mathrm{mmol} / \mathrm{L}$ \\
\hline POC Anion Gap & $25 \mathrm{mEq} / \mathrm{L}$ & 9-14 mEq/L \\
\hline POC Blood Urea Nitrogen & $43 \mathrm{mg} / \mathrm{dl}$ & $7-20 \mathrm{mg} / \mathrm{dl}$ \\
\hline POC Creatinine & $1.2 \mathrm{mg} / \mathrm{dl}$ & $0.60-1.20 \mathrm{mg} / \mathrm{dl}$ \\
\hline POC Lactic acid & $2.20 \mathrm{mmol} / \mathrm{L}$ & $0.5-2.2 \mathrm{mmol} / \mathrm{L}$ \\
\hline POC Glucose & $>700$ mg/dl & $65-100 \mathrm{mg} / \mathrm{dl}$ \\
\hline Urine PH & 5.0 & $4.6-8.0$ \\
\hline Urine specific gravity & 1.021 & $1.005-1.030$ \\
\hline Urine Ketone & $80 \mathrm{mg} / \mathrm{dL}$ & Small: $<20 \mathrm{mg} / \mathrm{dL}$, Moderate: 30 to $40 \mathrm{mg} / \mathrm{dL}$, Large: $>80 \mathrm{mg} / \mathrm{dL}$ \\
\hline Urine Protein & $30 \mathrm{mg} / \mathrm{dL}$ & $0-14 \mathrm{mg} / \mathrm{dL}$ \\
\hline Urine Glucose & $500>\mathrm{mg} / \mathrm{dl}$ & $0-15 \mathrm{mg} / \mathrm{dl}$ \\
\hline POC VBG PH & 7.025 & 7.31-7.41 \\
\hline POC VBG pCO2 & $25.4 \mathrm{mmhg}$ & $41-51 \mathrm{mmhg}$ \\
\hline POC VBG pO2 & $45 \mathrm{mmhg}$ & $30-40 \mathrm{mmhg}$ \\
\hline POC VBG HCO3 & $6.6 \mathrm{mmol} / \mathrm{L}$ & 23-29 mmo//L \\
\hline POC Base Excess & $-24 \mathrm{mEq} / \mathrm{L}$ & -2 to $+2 \mathrm{mEq} / \mathrm{L}$ \\
\hline
\end{tabular}

\section{TABLE 2: Laboratory investigations at time of hospital presentation}

POC: Point of Care ; VBG: Venous Blood Gas; dl: deciliter; L: liter; mEq: milliequivalent; mg: milligram; mmhg: millimeters of mercury; mmol: millimole

The patient was discharged on Insulin Glargine after stabilization and referred to our endocrinology clinic for further evaluation. On presentation, she had normal vital signs and physical examination was unremarkable except for a BMI of $27.86 \mathrm{~kg} / \mathrm{m} 2$ (normal reference range: 18.5 to $24.9 \mathrm{~kg} / \mathrm{m} 2$ ). Laboratory investigations were ordered, and the results were consistent with a new diagnosis of Type 1 diabetes mellitus (Table 3).

\begin{tabular}{|c|c|c|}
\hline Lab Marker & Finding & Reference \\
\hline Random Blood Sugar & 271 mg/dl & $65 \mathrm{mg} / \mathrm{dl}-100 \mathrm{mg} / \mathrm{dl}$ \\
\hline Hemoglobin A1C & $7.0 \%$ & $5.7 \%-6.4 \%$ \\
\hline GAD65 Antibodies Level & $250.0 \mathrm{lU} / \mathrm{ml}>$ & $0.0 \mathrm{IU} / \mathrm{ml}-5.0 \mathrm{IU} / \mathrm{ml}$ \\
\hline C-Peptide Level & $<0.05 \mathrm{ng} / \mathrm{ml}$ & $0.90 \mathrm{ng} / \mathrm{mL}-4.00 \mathrm{ng} / \mathrm{mL}$ \\
\hline
\end{tabular}

TABLE 3: Laboratory investigations following discharge from the hospital

GAD65: Glutamic acid decarboxylase; mg: milligram; dl: deciliter; IU: international unit; ml: milliliter; ng: nanograms 
be taken three times a day (TID) was added to her current medication regimen. She was counseled on her condition and advised to follow-up with the diabetes education team.

\section{Discussion}

Type 1 diabetes mellitus (T1DM) commonly occurs in children, with one in every four cases diagnosed in adults [3]. Various genetic and environmental factors contribute to the pathogenesis of this chronic condition. Autoimmunity is the underlying reason behind the destruction of the pancreatic $\beta$-cells and the depletion of its byproduct, insulin, which is a necessity in blood glucose homeostasis [5]. Recent studies now demonstrate that a fault in the $\beta$-cell gene sequence is behind the autoimmune destruction of the pancreas. This phenomenon, which was best observed in cancer patients who had received immunotherapy treatment, revealed that previously functioning $\beta$-cells began to produce non-functioning proteins, a feature commonly seen in cancer cells. This in turn prompts the normal antitumor response of the immune system against these pancreatic cells and therefore may explain why certain cancer patients develop T1DM after receiving immunotherapy treatment $[4]$.

Nivolumab is an Immunoglobulin G4 (IgG4) monoclonal antibody used in the treatment of various malignancies that works by blocking the activated T-cell PD-1/PD-L1 axis to suppress cell proliferation and neoplastic activation. Collectively, immunotherapy medications are called immune checkpoint inhibitors (ICI) and they all carry the risk of immune-related adverse events (irAE). The risk of severe hyperglycemia and immune-mediated diabetes mellitus with Nivolumab is $\leqslant 1 \%[7,8]$.

T1DM is diagnosed based on clinical and laboratory findings. In our patient, a sustained elevated blood sugar level and positive autoantibodies confirmed the diagnosis [3]. T1DM carries the risk of macrovascular and microvascular complications such as diabetic nephropathy, retinopathy, and cardiovascular disease [9]. It also carries the risk of DKA, a medical emergency, and the most common initial presentation in newly diagnosed T1DM [6]. Treatment is lifelong with tight glycemic control and insulin replacement [10]. As the frequency of ICI use increases, so does the frequency of irAE. Currently, there is a $10-20 \%$ risk of irAE in all patients using ICI [8]. This brings up the importance of discussing the risk of developing severe hyperglycemia and immune-mediated diabetes mellitus with Nivolumab immunotherapy and the significance of early recognition and intervention to prevent long-term complications.

\section{Conclusions}

The risk of developing severe hyperglycemia and immune-mediated diabetes mellitus in cancer patients receiving Nivolumab immunotherapy is $\leqslant 1 \%$. However, with the increasing use of immune checkpoint inhibitors (ICI), the risk of immune-related adverse events (irAE) also increases. Moreover, ICI may accelerate a pre-existing autoimmune process in patients with other autoimmune diseases or patients with a high propensity for developing autoimmune diseases, such as those with risk factors or a positive family history, thereby further increasing the risk of irAE. Therefore, it is important for physicians to be aware of these risks to be able to intervene early and reduce associated morbidity and mortality.

\section{Additional Information \\ Disclosures}

Human subjects: Consent was obtained or waived by all participants in this study. Conflicts of interest: In compliance with the ICMJE uniform disclosure form, all authors declare the following: Payment/services info: All authors have declared that no financial support was received from any organization for the submitted work. Financial relationships: All authors have declared that they have no financial relationships at present or within the previous three years with any organizations that might have an interest in the submitted work. Other relationships: All authors have declared that there are no other relationships or activities that could appear to have influenced the submitted work.

\section{References}

1. National Diabetes Statistics Report, 2020. (2020). Accessed: July 29, 2021: https://www.cdc.gov/diabetes/library/features/diabetes-stat-report.html.

2. Steck AK, Rewers MJ: Genetics of type 1 diabetes. Clin Chem. 2011, 57:176-85. 10.1373/clinchem.2010.148221

3. Epidemiology, presentation, and diagnosis of type 1 diabetes mellitus in children and adolescents . (2018). Accessed: July 24, 2021: https://www.uptodate.com/contents/epidemiology-presentation-and-diagnosis-oftype-1-diabetes-mellitus-in-children-and....

4. New potential cause of type 1 diabetes . (2017). Accessed: July 24, 2021: http://www.sciencedaily.com/releases/2017/03/170301085412.htm.

5. Ozougwu J, Obimba K, Belonwu C, Unakalamba C: The pathogenesis and pathophysiology of type 1 and type 2 diabetes mellitus. J Physiol Pathophysiol. 2013, 4:46-57. 10.5897/JPAP2013.0001

6. Westerberg DP: Diabetic ketoacidosis: evaluation and treatment. Am Fam Physician. 2013, 87:337-46.

7. Drug Name: Nivolumab. (2017). Accessed: July 24, 2021: http://www.bccancer.bc.ca/drug-databasesite/Drug\%20Index/Nivolumab_monograph.pdf.

8. Godwin JL, Jaggi S, Sirisena I, Sharda P, Rao AD, Mehra R, Veloski C: Nivolumab-induced autoimmune 


\section{Cureus}

diabetes mellitus presenting as diabetic ketoacidosis in a patient with metastatic lung cancer. J Immunother Cancer. 2017, 5:40. 10.1186/s40425-017-0245-2

9. Mahajan R: Blood test to help diagnose type 1 diabetes approved by Food and Drug Administration . Int J Appl Basic Med Res. 2015, 5:1. 10.4103/2229-516X.149215

10. Management of blood glucose in adults with type 1 diabetes mellitus . (2018). Accessed: July 24, 2021: https://www.uptodate.com/contents/management-of-blood-glucose-in-adults-with-type-1-diabetesmellitus. 